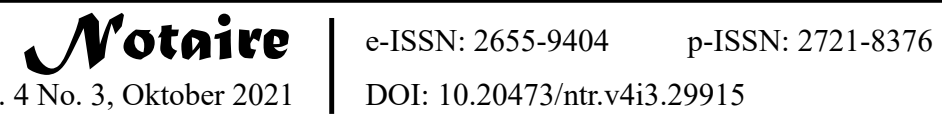

Article history: Submitted 14 September 2021; Accepted 24 September 2021; Available online 1 October 2021.

\title{
Analisis Perubahan Politik Hukum Dispensasi Perkawinan Pasca Undang-Undang Nomor 16 Tahun 2019
}

\author{
Trisadini Prasastinah Usanti, Xavier Nugraha \\ dan Dita Elvia Kusuma Putri \\ trisadini@fh.unair.ac.id \\ Universitas Airlangga
}

\begin{abstract}
In Article 7 paragraph (2) of Law Number 1 of 1974 concerning Marriage it is stated that in the event of a deviation from the minimal age of marriage, a marriage dispensation may be requested from the court or other official appointed by both male and female parents. However, there are no indicators related to the conditions for marriage dispensation to be proposed in Law Number 1 of 1974 making the legal politics of granting marriage dispensations focus on judges. In its development, was born Law Number 16 of 2019 replaced Law Number 1 of 1974. This article is a legal article with a statutory approach, a conceptual approach, and a case approach. Through this article, it was found that there was a political change in the marriage dispensation law in Law Number 16 Year 2019, where the politics of marriage dispensation law was stricter than Law Number 1 of 1974 and had the spirit not to easily provide marriage dispensation. This can be seen from the existence of two conditions for filing a dispensation in Law Number 16 of 2019, namely (1) having urgent reasons and (2) Having sufficient supporting evidence.

Keywords: Marriage Dispensation; Marriage Law; Politics Of Law.
\end{abstract}

\footnotetext{
Abstrak

Pasal 7 ayat (2) Undang-Undang Nomor 1 Tahun 1974 tentang Perkawinan disebutkan, bahwa dalam hal terjadi penyimpangan batas usia minimal perkawinan, maka dapat dimintakan dispensasi perkawinan kepada Pengadilan atau Pejabat lain yang ditunjuk oleh kedua orang tua pihak pria maupun pihak wanita. Namun, tidak ada indikator terkait kondisi dapat diajukannya dispensasi perkawinan di dalam Undang-Undang Nomor 1 Tahun 1974 membuat politik hukum pemberian dispensasi perkawinan, benar-benar menitikberatkan pada hakim. Dalam perkembangannya, lahir Undang-Undang Nomor 16 Tahun 2019 yang menggantikan Undang-Undang Nomor 1 Tahun 1974. Artikel ini merupakan artikel hukum dengan pendekatan peraturan perundang-Undangan (statute approach), pendekatan konseptual (conceptual approach), dan pendekatan kasus (case approach). Melalui artikel ini, ditemukan bahwa terjadi perubahan politik hukum dispensasi perkawinan di dalam Undang-Undang Nomor 16 Tahun 2019 , dimana politik hukum dispensasi perkawinan bersifat lebih ketat daripada Undang-Undang Nomor 1 Tahun 1974 dan memiliki semangat untuk tidak dengan mudah memberikan dispensasi perkawinan. Hal ini dapat terlihat dari adanya dua syarat diajukannya dispensasi di dalam Undang-Undang Nomor 16 Tahun 2019, yaitu (1) memiliki alasan mendesak dan (2) Memiliki bukti-bukti pendukung yang cukup. Kata Kunci: Dispensasi Perkawinan; Perkawinan; Politik Hukum. 


\section{Pendahuluan}

Het recht hink anter de feiten aan, sebuah ungkapan dalam Bahasa Belanda yang berarti bahwa hukum akan selalu mengejar fakta yang ada. ${ }^{1}$ Adagium hukum ini memiliki kedalaman makna, bahwa hukum yang ada akan selalu tertinggal dengan kondisi masyarakat yang diaturnya karena perkembangan yang terjadi di dalam masyrakat terjadi begitu cepat. ${ }^{2}$ Hukum di sini diartikan sebagai hukum tertulis atau Undang-Undang, sehingga dalam melakukan perubahan, harus melalui prosedur tertentu. Oleh sebab itu, tidak dimungkinkan serta-merta dilakukan perubahan Undang-Undang untuk segera disesuaikan dengan keadaan.

Salah satu Undang-Undang yang telah dilakukan perubahan untuk menyesuaikan dengan perkembangan zaman yang ada adalah Undang-Undang Nomor 16 Tahun 2019 Tentang Perubahan Atas Undang-Undang Nomor 1 Tahun 1974 Tentang Perkawinan (selanjutnya disebut UU 16/2019). UU 16/2019 ini lahir sebagai wujud pelaksanaan terhadap Putusan Mahkamah Konstitusi Nomor 22/PUUXV/2017 yang memerintahkan agar dilakukannya perubahan atas ketentuan batas usia perkawinan yang diatur di dalam Pasal 7 Undang-Undang Nomor 1 Tahun 1974 tentang Perkawinan (selanjutnya disebut UU 1/1974). Pada awalnya, batas usia minimal perkawinan yang diatur di dalam Pasal 7 UU 1/1974 adalah 16 tahun bagi wanita dan 19 tahun bagi pria. Dalam perkembangannya, Mahkamah Konstitusi melalui Putusan Nomor 22/PUUXV/2017 mengatakan bahwa perbedaan batas usia perkawinan tersebut bertentangan dengan prinsip persamaan di hadapan hukum (equality before the law) yang merupakan ciri utama negara demokrasi berlandaskan hukum (democracy state under the rule of law) yang diatur di dalam Pasal 27 Undang-Undang Dasar Negara Republik Indonesia Tahun 1945 (selanjutnya disebut UUD NRI 1945). ${ }^{3}$ Dengan ratio decidendi tersebut,

\footnotetext{
${ }^{1}$ Eddy O.S. Hiariej, ‘United Nations Convention Against Corruption Dalam Sistem Hukum Indonesia' (2019) 31 Mimbar Hukum.[113].

${ }^{2}$ Xavier Nugraha, Krisna Murti, dan Saraswati Putri, 'Third Parties' Legal Protection Over Agreed Authorized Capital Amount By Founders In Limited Liability Companies' (2019) 6 Lentera Hukum.[179].

3 Xavier Nugraha, Risdiana Izzaty, dan Annida Aqiila Putri, 'Rekonstruksi Batas Usia MinimalPerkawinan Sebagai Bentuk Perlindungan Hukum Terhadap Perempuan (Analisa Putusan MK No. 22/Puu-XV/2017)' (2019) 2 Lex Scientia.[41].
} 
Mahkamah Konstitusi kemudian memerintahkan kepada pembuat UndangUndang dengan untuk melakukan perubahan batas usia minimal perkawinan bagi pria dan wanita yang merefleksikan prinsip equality before the law.

Adanya amanat dari Mahkamah Konstitusi melalui Putusan Nomor 22/PUUXV/2017 untuk menetapkan batas usia minimal perkawinan yang merefleksikan prinsip equality before the law tersebutlah yang membuat pembentuk Undang-Undang mengubah batas usia minimal perkawinan bagi pria dan wanita sama-sama menjadi 19 tahun melalui UU 16/2019.4 Selain batas usia minimal perkawinan yang diubah, salah satu hal yang diubah di dalam UU 16/2019 adalah terkait dengan dispensasi perkawinan. Adanya perubahan pengaturan dispensasi perkawinan yang mengikuti perubahan usia perkawinan ini disebabkan karena ditakutkan dengan naiknya batas usia minimal perkawinan membuat pria dan wanita yang ingin melangsungkan perkawinan, namun tidak memenuhi syarat batas usia minimal perkawinan memanfaatkan dispensasi sebagai celah hukum. Oleh sebab itulah, pembentuk Undang-Undang tidak ingin disepensasi yang seharusnya bertujuan untuk memberikan pengecualian dalam kondisi-kondisi tertentu, malah digunakan sebagai celah hukum dan dimanfaatkan untuk melewati syarat batas usia minimal perkawinan.

Dengan dasar tersebut, pembentuk Undang-Undang merubah syaratsyarat dispensasi perkawinan menjadi lebih ketat, dengan harapan dispensasi perkawinan tidak dapat sembarang diajukan. Hal ini secara experis verbis ditulis di dalam Pasal 7 ayat (2) UU 16/2019 bahwa:

“Dalam hal terjadi penyimpangan terhadap ketentuan umur sebagaimana dimaksud pada ayat (1), orang tua pihak pria dan/atau orang tua pihak wanita dapat meminta dispensasi kepada Pengadilan dengan alasan sangat mendesak disertai bukti-bukti pendukung yang cukup".

Berdasarkan Pasal 7 ayat (2) UU 16/2019 tersebut, dapat dilihat bahwa dalam status a quo, jika ingin mengajukan dispensasi perkawinan harus memenuhi dua syarat kumulatif, yaitu:

\footnotetext{
${ }^{4}$ Ketentuan menimbang huruf c Undang-Undang Nomor 16 Tahun 2019 Tentang Perubahan Atas Undang-Undang Nomor 1 Tahun 1974 Tentang Perkawinan.
} 
1. Memiliki alasan mendesak;

2. Memiliki bukti-bukti pendukung yang cukup.

Jika dikomparasi dengan Pasal 7 ayat (2) UU 1/1974, hanya ditulis bahwa dispensasi perkawinan dapat diajukan kepada Pengadilan atau Pejabat lain yang ditunjuk oleh kedua orang tua pihak pria maupun pihak wanita. Hal ini menunjukan bahwa terdapat perbedaan politik hukum dispensasi perkawinan antara UU 1/1974 dengan UU 16/2019. Berdasarkan hal tersebut, maka artikel ini akan membahas terkait dengan perubahan politik hukum dispensasi perkawinan pasca UU 16/2019. Rumusan masalah dalam penelitian ini adalah (1) Politik hukum dispensasi perkawinan dalam Undang-Undang Nomor 1 Tahun 1974 Tentang Perkawinan dan (2) Politik hukum dispensasi perkawinan dalam UndangUndang Nomor 16 Tahun 2019 Tentang Perubahan Atas Undang-Undang Nomor 1 Tahun 1974 Tentang Perkawinan.

\section{Politik Hukum Dispensasi Perkawinan Dalam Undang-Undang Nomor 1 Tahun} 1974

Ad Recte docendum oportet primum inquirere nomina, quia rerum cognitio a nominimbus rerum dependet, perlu diketahui terlebih dahulu namanya, agar mendapatkan pengetahuan yang benar. ${ }^{5}$ Sebuah adagium hukum yang memiliki kedalaman makna, bahwa untuk memahami secara holistik suatu konsep hukum, maka harus diawali dari memahami definisinya terlebih dahulu. Oleh sebab itu, sebelum membahas mengenai dispensasi perkawinan secara khusus, maka perlu dipahami mengenai definisi dispensasi tersebut terlebih dahulu. Menurut Amrah Muslimin, dispensasi merupakan bagian dari perizinan (vergunning) yang berarti suatu pengecualian dari ketentuan umum, dalam hal mana pembuat undangundang sebenarnya dalam prinsipnya tidak berniat melakukan pengecualian. ${ }^{6}$ Dalam norma hukum, terdapat beberapa komponen norma, salah satunya ialah norma dispensasi yang berarti kebolehan khusus untuk tidak melakukan secara

${ }^{5}$ Eddy O.S. Hiariej, Prinsip-Prinsip Hukum Pidana Edisi Revisi (Cahaya Atama Pustaka 2015).[3].

${ }^{6}$ Adrian Sutedi, Hukum Perizinan Dalam Sektor Pelayanan Publik (Sinar Grafika2010).[25]. 
umum yang diperintahkan. ${ }^{7}$ Hal senada juga disampaikan oleh C.S.T Kansil dan Chistine S.T Kansil, makna dispensasi merupakan penetapan yang menyatakan bahwa suatu ketentuan peraturan memang tidak berlaku bagi kasus yang diajukan oleh seorang Pemohon. ${ }^{8}$

Berkaitan dengan dispensasi dalam hukum perkawinan adalah pemberian izin oleh pengadilan atau pejabat lain yang ditunjuk oleh orang tua kepada calon yang akan melangsungkan perkawinan pada usia dibawah standar yaitu usia kawin sebagaimana diatur dalam Pasal 7 ayat (1) UU 1/1974. Dalam Pasal 7 ayat (1) UU 1/1974 diatur bahwa perkawinan dizinkan apabila pria telah mencapai usia 19 (Sembilan belas) tahun dan wanita telah mencapai usia 16 (enam belas) tahun. Tujuan dari adanya batas minimal usia kawin menurut penjelasan Pasal 7 ayat (1) UU 1/1974 ialah menjaga kesehatan suami-isteri dan keturunan, sehingga adanya dispensasi tersebut merupakan upaya hukum bagi setiap orang yang ingin melakukan perkawinan dibawah batas usia minimal. Di samping itu, pengaturan batasan minimal usia perkawinan bertujuan agar calon suami istri tidak hanya masak raganya tetapi juga jiwanya agar tujuan perkawinan dapat tercapai tanpa diakhiri dengan perceraian. Lebih jauh disebutkan bahwa batasan usia minimal tersebut juga berhubungan dengan masalah kependudukan, yaitu menekan adanya laju kelahiran yang lebih tinggi.

Terkait dengan kompetensi absolut pengajuan permohonan dispensasi tersebut diajukan ke Pengadilan Agama bagi yang beragama Islam sesuai dengan Pasal13 Peraturan Menteri Agama Nomor 3 Tahun1975 tentang Kewajiban Pegawai Pencatat Nikah dan Tata Kerja Pengadilan Agama dalam Melaksanakan Peraturan Perundang-Undangan Perkawinan Bagi yang Beragama Islam (selanjutnya disebut Permenag 13/1975) dan Pengadilan Negeri bagi yang beragama non Islam sesuai dengan Petunjuk-Petunjuk Mahkamah Agung tanggal 20 Agustus 1975 No. M.A/Pemb/0807/75 Tentang Petunjuk-Petunjuk MA Mengenai Pelaksanaan

\footnotetext{
${ }^{7}$ I Dewa Gede Atmaja dan I Nyoman Putu Budiart, Teori- Teori Hukum (Setara Press 2018).[29]. 2001).[52].

${ }^{8}$ C.S.T Kansil dan Chistine S.T Kansil, Kamus Istilah Aneka Ilmu (Surya Multi Grafika
} 
Undang-Undang Nomor 1 Tahun 1974 dan Peraturan Pemerintah Nomor 9 tahun 1975. ${ }^{9}$ Terkait dengan kompetensi relatif pengajuan permohonan dispensasi tersebut, sesuai dengan Keputusan Ketua Mahkamah Agung Nomor KMA/032/ SK/IV/2006, maka permohonan tersebut diajukan ke pengadilan dalam wilayah hukum dimana calon mempelai tersebut tinggal.

Dalam Pasal 7 ayat (2) UU 1/1974 dijelaskan, bahwa dispensasi perkawinan diajukan oleh orang tua pria maupun wanita yang belum memenuhi usia minimal perkawinan. Selanjutnya, ketika pengadilan mengabulkan permohonan dispensasi perkawinan, maka akan dikeluarkan penetapan dispensasi perkawinan, dan salinan penetapan tersebut dapat dijadikan sebagai persyaratan melangsungkan perkawinan. ${ }^{10}$ Dengan demikian, bagi pasangan yang tidak memenuhi batas usia minimal, maka penetapan dispensasi perkawinan yang dikeluarkan pengadilan adalah syarat formil tambahan yang harus dimiliki oleh pasangan tersebut.

Problematika hukum yang ada dalam dispensasi perkawinan di UU 1/1974 adalah tidak adanya secara jelas pengaturan mengenai alasan atau indikatorindikator secara pasti yang dapat dijadikan sebagai alasan agar diberikannya dispensasi perkawinan. ${ }^{11}$ Bahkan, di dalam Peraturan Pemerintah Nomor 9 Tahun 1975 Tentang Peraturan Pelaksana Undang-Undang Nomor 1 Tahun 1974 Tentang Perkawinan (selanjutnya disebut PP 9/1975) yang notabene merupakan peraturan teknis dari UU 1/1974 juga tidak terdapat pengaturan teknis apapun terkait dispensasi perkawinan. Sehingga, dapat dikatakan bahwa di dalam UU 1/1974 dan PP 9/1975 tidak terdapat indikator yang pasti mengenai syarat diajukannya dispensasi perkawinan.

Jika dilihat di dalam UU 1/1974 dan PP 9/1975, selain tidak adanya indikator terkait dengan alasan dapat diajukannya perkawinan, problematika yang hukum yang lain adalah batas usia minimal dapat diajukannya dispensasi

\footnotetext{
${ }^{9}$ Sri Ahyani,'Pertimbangan Pengadilan Agama Atas Dispensasi Pernikahan Usia Dini Akibat Kehamilan Di Luar Nikah'(2016) 34 Jurnal Wawasan Hukum.[39].

${ }^{10}$ Moh.Idris Ramulyo, Hukum Perkawinan Islam (Sinar Grafindo 1999).[183]

${ }^{11}$ Ramadhita, 'Diskresi Hakim:Pola Penyelesaian Kasus Dispensasi Perkawinan'(2014) 6 De Jure Jurnal Syariah dan Hukum.[61].
} 
perkawinan tersebut. ${ }^{12}$ Dengan tidak adanya ketentuan sama sekali terkait dengan batas usia minimal perkawinan dapat diajukannya dispensasi, maka hal ini membuat terjadinya kekosongan hukum terkait dengan batas usia minimal dapat diajukannya dispensasi perkawinan. Hal ini berarti, bahkan tidak menutup kemungkinan anak berusia satu tahun dapat diajukan dispensasi perkawinan. Bilamana dilihat dalam ketentuan lain, misal terkait dengan usia anak yang dapat berkonflik dengan hukum (dapat dipidana), terdapat ketentuan batas minimal, yaitu 12 (dua belas) tahun sesuai dengan Pasal 1 angka 3 Undang-Undang Nomor 11 Tahun 2012 Tentang Sistem Peradilan Anak (selanjutnya disebut UU 11/2012).

Dengan tidak adanya ketentuan yang mengatur secara jelas terkait indikator dispensasi perkawinan dan belum adanya batas usia minimal diajukannya dispensasi perkawinan, maka dapat dikatakan bahwa ketentuan akan dispensasi perkawinan ini masih bersifat abu-abu. ${ }^{13} \mathrm{Hal}$ tersebut, menyebabkan terdapat ruang yang besar bagi hakim untuk memutus terkait dengan dispensasi perkawinan. ${ }^{14}$ Hakim memiliki peran yang besar untuk bertugas untuk menentukan dapat atau tidaknya dispensasi perkawinan diberikan. Adapun dasar pertimbangan hakim yang digunakan secara umum terkait dengan pemberian dispensasi perkawinan adalah sebagai berikut: ${ }^{15}$

1. Pemohon

Majelis Hakim di dalam persidangan akan meneliti apakah orang yang mengajukan perkara permohonan dispensasi tersebut berhak mengajukan atau tidak;

2. Alasan

Pada persidangan Majelis Hakim menanyakan alasan anak pemohon, kemudian Majelis Hakim meneliti alasan anak pemohon dengan pemohon disurat permohonannya. Apakah alasan anak pemohon dengan pemohon ada persamaan atau tidak;

\footnotetext{
${ }^{12}$ Nizar Abdussalam, 'Batas Minimal Usia Kawin Perspektif Hakim Pengadilan Agama dan Dosen Psikologi UIN Malang' (2015) 6 Jurisdictie: Jurnal Hukum dan Syariah.[93].

${ }_{13}$ Dhorifah Hafidhotul Hikmah, Agung Basuki Prasetyo, dan Triyono, 'Pengaruh Batas Usia Kawin Dalam Undang-Undang Nomor 1 Tahun 1974 Terhadap Jumlah Perkawinan Dibawah Umur Di Kabupaten Rembang Provinsi Jawa Tengah' (2017) 6 Diponegoro Law Journal.[7].

${ }^{14}$ Nur Aisyah, 'Dispensasi Pernikahan Di Bawah Umur Pada Masyarakat Islam Di Kabupaten Bantaeng' (2017) 4 Jurisprudentie.[177].

15 Bagya Agung Prabowo, 'Pertimbangan Hakim dalam Penetapan Dispensasi Perkawinan Dini Akibat Hamil di Luar Nikah pada Pengadilan Agama Bantul’ (2013) 2 Ius Quiaistum.[305].
} 
3. Terdapat larangan perkawinan atau tidak

Bagi pria atau yang akan melangsungkan pernikahan terdapat halangan atau tidak, sebagaimana yang diatur dalam Undang-Undang Perkawinan;

4. Kemaslahatan dan kemudharatan

Dalam hukum Islam bila pria dan wanita melakukan hubungan seksual di luar nikah yang menyebabkan kehamilan, maka Pengadilan akan mengabulkan permohonan dispensasi tersebut, karena dikhawatirkan bila tidak dinikahkan akan terjadi pelanggaran norma agama, norma kesusilaan secara terus menerus yang ada di masyarakat dan terjadi perkawinan di bawah tangan yang akan mengacaukan proses-proses hukum yang akan terjadi berikutnya atau mengacaukan hak-hak hukum anak yang dilahirkannya menurut undang-undang.

Dalam mempertimbangkan penetapan dispensasi perkawinan hakim bertugas untuk mengkonstatir (mengkonstatasi), mengkualifisir (mengkualifikasi) dan kemudian mengkonstituir (mengkonstitusi). ${ }^{16}$ Mengkonstatir artinya hakim harus menilai apakah peristiwa atau fakta-fakta yang dikemukakan oleh para pihak itu adalah benar-benar terjadi. Hal ini hanya dapat dilakukan melalui pembuktian ${ }^{17}$ Dalam mempertimbangkan, hakim mendasarkan pada pertimbangan hukum yang berarti penetapannya tidaklah bertentangan dengan peraturan perundang-undangan dan sesuai dengan dalil-dalil serta barang bukti yang diajukan pemohon.

Dapat dilihat, bahwa ternyata Hakim dalam menentukan pemberian dispensasi perkawinan, tidak hanya menggunakan landasan yuridis, namun juga harus berdasarkan pertimbangan atau alasan-alasan lain, misalkan faktor sosiologis seperti nilai-nilai di masyarakat pasangan tersebut, contoh: Perkawinan kekerabatan Bani Kamsidin dimana perkawinan hanya boleh dilakukan dengan keturunan dari desa/marga/kasta/keluarga yang berasal dari keturunan yang sama yaitu Kamsidin terjadi di Desa Banjar Tabulu, Camplong, Sampang, Madura ${ }^{18}$ Umumnya Bani Kamsidin melakukan perkawinan kekerabatan diawali

${ }^{16}$ ibid.[306].

${ }^{17}$ Sri Ahyani,'Pertimbangan Pengadilan Agama Atas Dispensasi Pernikahan Usia Dini Akibat Kehamilan Di Luar Nikah'(2016) 34 Jurnal Wawasan Hukum.[41].

${ }^{18}$ Siti Zya Ama 'Pernikahan Kekerabatan Bani Kamsidin (Studi Kasus Pernikahan Endogami Di Jawa Timur Tahun 1974-2015 M)’ (2017) 1 JUSPI: Jurnal Sejarah Peradaban Islam.[321-322]. 
dengan perjodohan dini. ${ }^{19}$ Oleh karenanya, Hakim disini sangat berperan dalam menetapkan dispensasi perkawinan berdasarkan keyakinannya yang memperhatikan aspek hukum dan aspek sosiologis yang hidup di masyarakat. Hal ini sesuai dengan Pasal 5 Undang - Undang Nomor 48 Tahun 2009 Tentang Kekuasaan Kehakiman, dimana hakim dituntut untuk menggali, mengikuti, dan memahami nilai-nilai hukum dan rasa keadilan yang hidup dalam masyarakat, dalam menjatuhkan putusan. Hal ini sesuai dengan adagium hukum yaitu judex herbere debet duos sales, salem sapientiae, ne sit insipidus, et salem conscientiae, ne sit diabolus, yang berarti seorang hakim harus mempunyai dua hal, yaitu kebijaksanaan kecuali dia adalah orang yang bodoh dan hati nurani, kecuali dia mempunyai sifat yang kejam.

Pengaturan terkait pemberian dispensasi perkawinan yang sangat bergantung dengan keyakinan hakim, maka seharusnya hakim harus teliti dan berhati-hati dalam mengeluarkan penetapan dispensasi perkawinan. Namun, ternyata dalam praktiknya banyak sekali hakim tidak menggunakan pertimbangan yang tepat dalam memberikan dispensasi perkawinan. Cum adsunt testimonia rerum quid opus est verbis, saat bukti dan fakta sudah ada, apa guna kata-kata. Ketidakcermatan hakim dalam memberikan dispensasi perkawinan di Indonesia dapat dilihat dari begitu tingginya angka dispensasi perkawinan yang diberikan oleh hakim. Misal, berdasarkan data, dispensasi perkawinan dibawah umur di wilayah Pengadilan Agama se-Ex Karesidenan Surakarta setiap tahunnya cenderung meningkat, misal di Kabupaten Boyolali pada tahun 2012 terdapat 36 permohonan dispensasi perkawinan, pada 2014 naik menjadi 66 permohonan dan pada 2016 naik lagi menjadi 92 permohonan dispensasi perkawinan. ${ }^{20} \mathrm{Di}$ wilayah lain, misal di Indramayu, pada Pada 2016, perkara dispensasi kawin yang diajukan ke Pengadilan Agama mencapai 350 perkara dan diputus sebanyak 324 perkara. Sementara pada 2015, pengajuan dispensasi kawin mencapai 459 kasus

\footnotetext{
19 ibid.[327].

${ }^{20}$ M.Muslih, 'Dispensasi Perkawinan di Bawah Umur (Studi Pertimbangan Hakim dalam Memberikan Dispensasi Perkawinan di Peradilan Agama Se-ex Kerasidenan Surakarta) (2018).[5].
} 
dan dikabulkan sebanyak 419 kasus. ${ }^{21}$ Demikian juga pada Pengadilan Agama Rantau tercatat pada tahun 2016 perkara yang diterima sebanyak 538 perkara dan 39 perkara diantaranya adalah perkara dispensasi kawin. Pada Tahun 2017 sampai bulan Juli 2017 perkara yang diterima sebanyak 262 perkara dan 29 perkara tentang dispensasi kawin. ${ }^{22} \mathrm{Hal}$ ini menunjukkan bahwa permohonan penetapan dispensasi kawin cukup tinggi yang diajukan ke Pengadilan Agama.

Tingginya angka dispensasi perkawinan yang ada di Indonesia menunjukan bahwa, seolah-olah dispensasi perkawinan hanya menjadi syarat formil tambahan bagi pasangan yang berusia di bawah batas usia minimal yang diatur di dalam Pasal 7 ayat (1) UU 1/1974. Seolah-olah hakim pasti akan mengabulkan permohonan dari pasangan yang belum berusia di bawah batas usia minimal yang diatur di dalam Pasal 7 ayat (1) UU 1/1974, tanpa menggunakan pertimbangan yang tepat. Hal ini membuat filosofi dari penyerahan ruang yang besar bagi hakim (Persoonlijke of Rechtspositionele Onafhankelijkheid) untuk memutus dispensasi perkawinan dengan tujuan menggunakan pertimbangan sesuai nilai-nilai hukum dan rasa keadilan yang hidup dalam masyarakat menjadi seolah-olah hilang. ${ }^{23}$ Pengesahan hakim seolah-olah hanya formalitas belaka yang pasti akan terpenuhi, selama terpenuhinya syarat-syarat administrasi dalam mengajukan dispensasi perkawinan.

Secara empirik, di Indonesia penyebab terjadi perkawinan anak di bawah usia minimal kawin ialah karena faktor ekonomi keluarga yang mengalami kesulitan, faktor sosial, faktor budaya serta faktor tempat tinggal. ${ }^{24}$ Misalkan di Dusun Menco, Kelurahan Berahan Wetan, Kecamatan Wedung, Kabupaten Demak, Jawa Tengah sering terjadi perkawinan dini yang dipaksakan oleh orang

${ }^{21}$ Dea Agustina Suardini, Yunanto, dan Mas'ut, 'Pelaksanaan Perkawinan Di Bawah Umur Melalui Dispensasi Pengadilan Agama Kabupaten Indramayu', (2013) 1 Diponegoro Law Review.[6]

${ }^{22}$ St. Zubaidah, Dispensasi Kawin Dalam Tinjauan Undang-Undang Nomor 23 Tahun 2002 Tentang perlindungan Anak, http://pa-purworejo.go.id/web/dispensasi-kawin-dalam-tinjauanuu-no-23-tahun-2002/.

${ }^{23}$ Firman Floranta Adonara, 'Prinsip Kebebasan Hakim dalam Memutus Perkara Sebagai Amanat Konstitusi' (2015) Jurnal Konstitusi.[224].

${ }^{24}$ Mariyatul Qibtiyah, 'Faktor Yang Mempengaruhi Perkawinan Muda Perempuan' (2014) Jurnal Biometrika dan Kependudukan.[51]. 
tua dikarenakan orang tua mengalami kesulitan ekonomi dan menginginkan tali silaturahmi antara keluarga tidak putus. ${ }^{25}$ Tentu dengan pengaturan Pasal 7 ayat (2) UU 1/1974 tidaklah dapat menyelesaikan permasalahan seperti yang terjadi di di atas. Dengan demikian, seharusnya keterangan dari pria dan wanita calon mempelai harus di hadirkan dalam pembuktian dan digunakan sebagai pertimbangan hakim guna mengantisipasi adanya paksaan dari kedua orang tua mempelai. Di samping alasan tersebut, banyaknya dispensasi diberikan oleh Pengadilan Agama karena terjadi kehamilan di luar nikah sebagaimana contoh pada Penetapan Nomor 0978/Pdt.P/2017/PA.Kab.Mlg. Bahkan berdasarkan penelitian yang dilakukan di Pengadilan Agama Yogyakarta dari tahun 20102015 ada 248 perkara permohonan dispensasi kawin, yaitu 34 perkara tahun 2010, 56 perkara tahun 2011, 37 perkara tahun 2012, 44 perkara tahun 2013, 41 perkara tahun 2014 dan 36 perkara tahun 2015 dari keseluruhan permohonan dispensasi kawin alasan yang sering diajukan adalah sudah terlanjur hamil di luar nikah. ${ }^{26}$

Mekanisme permohonan dispensasi perkawinan yang di atur dalam UU 1/1974 tidaklah mencerminkan semangat untuk mewujudkan tujuan dari perkawinan yaitu membentuk keluarga yang bahagia dan kekal berdasarkan Ketuhanan Yang Maha Esa sebagaimana tercantum dalam Pasal 1 UU 1/1974. Penetapan dispensasi seharusnya mempertimbangkan semangat pencegahan perkawinan anak, pertimbangan moral, agama, adat dan budaya, aspek psikologis, aspek kesehatan dan dampak yang ditimbulkan akibat perkawinan di bawah usia minimal kawin.

Dengan tidak adanya aturan terkait indikator dispensasi perkawinan di dalam UU 1/1974 dan PP 9/1975 dan kewenangan penilaiannya diberikan ke hakim, dan permohonan dispensasi tersebut seolah-olah selalu dikabulkan, tentu meyimpang dari tujuan dispensasi perkawinan itu sendiri. Dispensasi perkawinan sebagai perlindungan hukum harusnya diberikan dalam keadaan tertentu yang

${ }^{25}$ Arif Hakiem, 'Pernikahan Dini Karena Paksaan Orang Tua (Studi Kasus di Dusun Menco Kelurahan Berahan Wetan, Kecamatan Wedung, Kabupaten Demak' (2009) Restorasi Hukum.[5].

${ }^{26}$ Nurul Inayah, 'Penetapan Dispensasi Nilah Akibat Hamil di Luar Nikah di Pengadilan Agama Yogyakarta Tahun 2010-2015 (Analisis Hukum Acara Peradilan Agama)’ (2017) 10 Al-Ahwal.[2]. 
sangat memaksa dan mendesak untuk dilakukan perkawinan. Bukan malah dimanfaatkan sebagai celah hukum.

Dengan demikian, dapat disimpulkan bahwa politik hukum ${ }^{27}$ dispensasi perkawinan di dalam UU 1/1974 masih memberikan ruang yang besar bagi hakim dalam mengeluarkan penetapan dispensasi perkawinan. Indikator permohonan dispensasi yang tidak di atur secara jelas dalam UU 1/1974 dan tidak adanya keterlibatan kedua calon mempelai dalam pembuktian sehingga hakim berperan besar dalam dikeluarkannya penetapan dispensasi dan sering dimanfaatkan sebagai celah hukum oleh masyarakat merupakan politik hukum dispensasi perkawinan di dalam UU 1/1974.

\section{Politik Hukum Dispensasi Perkawinan Dalam Undang-Undang Nomor 16} Tahun 2019

Setelah memahami bahwa politik hukum dispensasi perkawinan di dalam UU 1/1974 masih memberikan memberikan ruang yang besar bagi hakim dalam mengeluarkan penetapan dispensasi perkawinan, maka akan dianalisis terkait dengan politik hukum dispensasi perkawinan dalam UU 16/2019 yang notabene merupakan perubahan dari UU 1/1974. Secara umum, perubahan fundamental yang ada di dalam UU 16/2019 adalah terkait dengan batas usia minimal perkawinan yang sebelumnya 16 tahun bagi wanita dan 19 tahun bagi pria menjadi sama-sama 19 tahun, baik bagi pria dan wanita. Kenaikan batas usia minimal perkawinan sebanyak 3 (tiga) tahun bagi wanita tersebut ditakutkan akan menyebabkan semakin meningkatnya pengajuan dispensasi perkawinan kedepannya. Ketakutan ini logis, mengingat pada usia 16 tahun bagi wanita saja banyak diajukannya dispensasi perkawinan, apalagi ketika batas usianya ditingkatkan menjadi batas usia 19 tahun bagi wanita dan pria. Tentunya memungkinkan semakin banyak dispensasi perkawinan yang diajukan.

27 Politik hukum adalah kebijakan hukum (legal policy) yang hendak diterapkan atau dilaksanakan oleh suatu pemerintahan negara tertentu, selengkapnya Mahfud MD, Membangun Politik Menegakkan Konstitusi (Rajawali Pers 2010).[15]. 
Bisa-bisa, nantinya batas usia minimal perkawinan yang sama-sama diubah menjadi 19 tahun bagi pria dan wanita yang bertujuan untuk menciptakan persamaan hak dihadapan hukum (equality before the law) bagi pria dan wanita agar sama-sama dapat menikmati hak sebagai anak secara penuh ${ }^{28}$ bisa menjadi tercederai. ${ }^{29}$ Nantinya, tujuan dari adanya kenaikan batas usia minimal perkawinan di dalam UU 16/2019 sebagai bentuk perlindungan hukum terhadap hak anak bagi perempuan, bisa tercederai dengan adanya dispensasi perkawinan jika bentuk dispensasi perkawinan tersebut sama seperti UU 1/1974. Oleh sebab itu, pembentuk Undang-Undang yang juga notabene bertugas melakukan evaluasi terhadap pelaksanaan suatu undang-undang, dimana dalam hal ini mengevaluasi pelaksanaan dispensasi perkawinan di dalam UU 1/1974, merasa bahwa jika pengaturan dispensasi perkawinan sama seperti UU 1/1974, nantinya akan digunakan sebagai celah hukum atau legal loophole. ${ }^{30}$

Perubahan yang dilakukan dalam rangka mencegah adanya penggunaan dispensasi perkawinan sebagai celah hukum adalah dengan memperketat syarat dispensasi perkawinan yang ada. Jika sebelumnya politik hukum dispensasi perkawinan yang ada di dalam UU 1/1974 memberikan kewenangan yang besar bagi hakim dalam menentukan pemberian dispensasi perkawinan, maka dalam UU 16/2019, pembentuk Undang-Undang menambah syarat-syarat pemberian dispensasi. Hal ini dapat dilihat di dalam ketentuan Pasal 7 ayat (2) UU 16/2019, yaitu:

“Dalam hal terjadi penyimpangan terhadap ketentuan umur sebagaimana dimaksud pada ayat (1), orang tua pihak pria dan/atau orang tua pihak wanita dapat meminta dispensasi kepada Pengadilan dengan alasan sangat mendesak disertai bukti-bukti pendukung yang cukup"

Berdasarkan ketentuan di atas maka dispensasi dapat dilakukan dengan 2 (dua) syarat kumulatif, yaitu memiliki alasan mendesak dan memiliki bukti-bukti

\footnotetext{
${ }^{28}$ Sesuai dengan Pasal 1 angka 1 Undang-Undang Nomor 35 Tahun 2014 Tentang Perubahan atas Undang-Undang Nomor 23 Tahun 2002 Tentang Perlindungan Anak, anak adalah seseorang yang belum berusia 18 (delapan belas) tahun.

${ }^{29}$ Xavier Nugraha, Risdiana Izzaty, dan Annida Aqiila Putri., Op.Cit.[54].

${ }^{30}$ Khopiatuziadah, 'Evaluasi Dan Analisis Peraturan Perundang-Undangan Dalam Penyusunan Naskah Akademik' (2016) 5 Rechtsvinding.[3].
} 
pendukung yang cukup. Berikut, akan dijabarkan lebih lanjut berkaitan dengan 2 (dua) syarat kumulatif sebagai berikut:

1. Memiliki alasan mendesak

Di dalam Lampiran I Undang-Undang Nomor 12 Tahun 2011 Tentang Peraturan Perundang-Undangan, dijelaskan dalam angka 176, bahwa:

“Penjelasan berfungsi sebagai tafsir resmi pembentuk Peraturan Perundangundangan atas norma tertentu dalam batang tubuh. Oleh karena itu, penjelasan hanya memuat uraian terhadap kata, frasa, kalimat atau padanan kata/istilah asing dalam norma yang dapat disertai dengan contoh. Penjelasan sebagai sarana untuk memperjelas norma dalam batang tubuh tidak boleh mengakibatkan terjadinya ketidakjelasan dari norma yang dimaksud".

Hal tersebutmenunjukan, bahwa penjelasan peraturan perundang-undangan merupakan tafsir resmi pembentuk Undang-Undang. Hal tersebut berarti, untuk dapat memahami maksud pembentuk Undang-Undang harus melihat pada penjelasan peraturan perundang-undangan tersebut. Pentingnya pemahaman maksud pembuat Undang-Undang melalui penjelasan agar memahami suatu norma dalam peraturan perundang-undangan ini sejatinya sesuai dengan asas hukum yaitu scire leges non hoc est verba earum tenere, sed vim ac potestatem, yang berarti meskipun Undang-Undang telah tertulis secara jelas, namun harus dipahami maksud dari pembuat Undang-Undang tersebut.

Dalam konteks untuk memahami alasan mendesak yang dimaksud oleh pembuat UU 16/2019, maka harus melihat pada penjelasan UU 16/2019. Di dalam penjelasan UU 16/2019 disebutkan bahwa yang dimaksud alasan mendesak adalah keadaan tidak ada pilihan lain dan sangat terpaksa harus dilangsungkan perkawinan. Hal ini berarti, nantinya ketika pemohon mengajukan permohonan dispensasi perkawinan, maka pemohon harus menguraikan alasan tidak adanya pilihan lain, sehingga dengan terpaksa harus dilangsungkan perkawinan. Sehingga, nantinya diharapkan hakim melakukan penilaian terhadap alasan tersebut, dimana ketika masih adanya pilihan lain selain dispensasi perkawinan, maka pilihan lain tersebut yang harus diambil. Misal alasan mendesak tersebut adalah karena telah terjadi hamil di luar nikah, padahal wanita tersebut belum berusia 19 tahun. Ketika tidak dibolehkannya dilangsungkan perkawinan, maka 
akan menyebabkan tidak adanya perlindungan hukum bagi wanita dan juga anak yang dikandung oleh wanita tersebut.

2. Memiliki bukti-bukti pendukung yang cukup

Dalam hukum pembuktian, secara umum terdapat asas beban pembuktian (bewijlast leer) yang berbunyi actori incumbit probatio, artinya siapa yang mendalilkan, dialah yang wajib membuktikan. ${ }^{31}$ Sejumlah asas lain yang berkaitan adalah affirmanti non neganti incumbit probatio, pembuktian bersifat wajib bagi yang mengiyakan, bukan yang menyangkal dan affirmantis est probare, yang berarti orang yang mengiyakan, harus membuktikan. Inti dari asas-asas hukum tersebut adalah pihak yang mendalilkan wajib melakukan pembuktian. Asas-asas hukum ini kemudian menjadi landasan lahirnya Pasal 1865 Burgelijk Wetbook (selanjutnya disebut BW) jo. Pasal 163 Herzien Inlandsch Reglement (selanjutnya disebut HIR)/283 Rechtsreglement voor de Buitengewesten yang dalam hukum acara perdata menempatkan beban pembuktian pada pihak yang mendalilkan. ${ }^{32}$

Dalam konteks permohonan dispensasi perkawinan, maka untuk mendukung dalil alasan mendesak yang diajukan pemohon, maka pemohon wajib menyertakan bukti-bukti pendukung yang cukup. Berdasarkan penjelasan Pasal 7 UU 16/2019 disebutkan bahwa yang dimaksud dengan bukti-bukti pendukung yang cukup adalah adalah surat keterangan yang membuktikan bahwa usia mempelai masih di bawah ketentuan undang-undang dan surat keterangan dari tenaga kesehatan yang mendukung pernyataan orang tua bahwa perkawinan tersebut sangat mendesak untuk dilaksanakan. Secara umum di dalam hukum acara perdata, di dalam Pasal 1866 jo. Pasal 164 HIR, disebutkan bahwa alat bukti adalah:

1. Surat;

2. Saksi;

3. Persangkaan;

4. Pengakuan;

5. Sumpah.

\footnotetext{
${ }^{31}$ Moch. Iqbal, 'Aspek Hukum Class Action Dan Citizen Law Suit Serta Perkembangannya Di Indonesia' (2012) 1 Jurnal Hukum dan Peradilan.[91].

${ }^{32}$ Maria Rosalina, 'Pengaturan Pemeriksaan Setempat (decentee) Dalam Peraturan PerundangUndangan Di Indonesia’ (2018) 18 Jurnal Hukum Kaidah.[2].
} 
Kelima bukti tersebut bersifat hierarkis, artinya semakin tinggi hierarki alat bukti tersebut, maka semakin kuat kekuatannya. ${ }^{33}$ Namun, dalam konteks pengajuan dispensasi perkawinan dalam UU 16/2019, bukti-bukti pendukung yang cukup hanya terlimitasi pada bukti surat, khusunya surat keterangan yang membuktikan bahwa usia mempelai masih di bawah ketentuan undang-undang dan surat keterangan dari tenaga kesehatan yang mendukung pernyataan orang tua bahwa perkawinan tersebut sangat mendesak untuk dilaksanakan. Ini artinya, alat bukti saksi, persangkaan, pengakuan, dan sumpah tidak bisa digunakan sebagai dasar pengajuan dispensasi perkawinan.

Adapun yang dimaksud surat keterangan yang membuktikan bahwa usia mempelai masih di bawah ketentuan undang-undang, artinya pemohon harus mampu mennjukan bahwa usia ketika diajukan dispensasi perkawinan tersebut tidak bertentangan dengan Undang-Undang lain, misal di dalam UU 11/2012. Terkait dengan surat keterangan dari tenaga kesehatan yang mendukung pernyataan orang tua bahwa perkawinan tersebut sangat mendesak untuk dilaksanakan, misal surat keterangan dari dokter yang menyatakan, bahwa wanita yang hamil di luar nikah tersebut benar-benar dalam kondisi hamil. Hal ini untuk memastikan, bahwa wanita tersebut benar-benar hamil secara medis, bukan hanya sekadar asmusi belaka. Misal asumsi bahwa wanita pasti hamil karena melakukan hubungan seks dengan seorang pria, tidak bisa menjadi dasar untuk mengajukan dispensasi perkawinan.

Dengan adanya, ketentuan yang mewajibkan bagi pemohon untuk mendalilkan alasan mendesak dengan menyertakan bukti pendukung yang cukup di dalam UU 16/2019, maka dapat dilihat bahwa politik hukum dispensasi perkawinan di dalam UU 16/2019 tidak lagi memberikan ruang bagi hakim dalam memberikan dispensasi perkawinan sebesar UU 1/1974. Bahkan, di dalam Penjelasan Pasal 7 ayat (3), disebutkan bahwa :

Pemberian dispensasi oleh Pengadilan Agama bagi mereka yang beragama

${ }^{33}$ Maisara Sunge, ‘Beban Pembuktian Dalam Perkara Perdata' (2012) 9 Jurnal INOVASI.[8]. 
Islam dan Pengadilan Negeri bagi yang beragama lainnya berdasarkan pada semangat pencegahan perkawinan anak, pertimbangan moral, agama, adat dan budaya, aspek psikologis, aspek kesehatan, dan dampak yang ditimbulkan.

Hal ini berarti hakim dalam memberikan dispensasi perkawinan juga diwajibkan untuk mempertimbangkan terkait dengan semangat pencegahan perkawinan anak, dimana hakim dituntut untuk berhati-hati dalam memberikan dispensasi bagi pria dan wanita dibawah usia 18 tahun. Selain itu, hakim juga dituntut untuk mempertimbangkan aspek moral,agama,adat dan budaya, psikologis, kesehatan, dan dampak yang ditimbulkan ketika diberikannya dispensasi perkawinan. Hal ini menunjukan, bahwa politik hukum dispensasi perkawinan di dalam UU 16/2019 lebih ketat daripada UU 1/1974 dan memiliki semangat untuk tidak dengan mudah memberikan dispensasi perkawinan. Bahkan, di dalam Penjelasan Pasal 7 UU 16/2019, disebutkan bahwa Pemerintah wajib melakukan sosialisasi dan pembinaan kepada masyarakat mengenai pencegahan perkawinan usia dini, bahaya seks bebas dan perkawinan tidak tercatat demi terwujudnya generasi bangsa yang lebih unggul. Hal ini sebagai upaya preventif terjadi kejadiankejadian yang dapat menyebabkan dikeluarkannya dispensasi perkawinan.

Di samping itu, berdasarkan Peraturan Mahkamah Agung Republik Indonesia Nomor 5 Tahun 2019 tentang Pedoman Mengadili Permohonan Dispensasi Kawin (PERMA 5/2019) bahwa hakim yang mengadili permohonan dispensasi kawin harus mendasarkan pada 10 asas, yaitu asas kepentingan terbaik bagi anak, asas hak hidup dan tumbuh kembang anak, asas perhargaan atas pendapat anak, asas perhargaan atas harkat dan martabat manusia, asas non diskriminasi, asas kesetaraan gender, asas persamaan di depan hukum, asas keadilan, asas kemanfaatn dan asas kepastian hukum. Maka pedoman ini bertujuan agar asas-asas tersebut dapat diterapkan, menjamin pelaksanaan sistem peradilan yang melindungi hak anak, meningkatkan tanggung jawab orang tua dalam rangka mencegah perkawnan anak, mengindetifikasi ada atau tidaknya paksaan yang melatar belakangi pengajuan permohonan dispesansi kawin dan mewujudkan standarisasi proses mengadili permohonan dispensasi kawin di Pengadilan. 
Perwujudan dari asas-asas tersebut, maka dalam pemeriksaan perkara pada hari pertama sidang, pemohon wajib menghadirkan:

a. Anak yang dimintakan permohonan dispensasi kawin;

b. Calon suami/istri;

c. Orang tua/wali calon suami/istri.

Menghadirkan pihak-pihak tersebut di atas merupakan kewajiban dari pemohon. Bilamana tidak dapat menghadirkan pada sidang pertama atau sidang kedua atau pada sidang ketiga maka permohonan dispensasi kawin tidak dapat diterima. Hal ini dilakukan oleh hakim dalam rangka menggali alasan yang sangat mendesak mengapa dilakukan perkawinan dari calon pasangan yang masih dibawah usia minimal kawin sehingga hakim harus mendengar keterangan langsung dari anak yang dimintakan dispensasi kawin, calon suami/istri yang dimintakan dispensasi kawin, orang tua/wali anak yang dimohonkan dispensasi kawin dan dari orang tua/wali calon suamu/istri.

Di dalam PERMA 5/2019, hakim harus mengidentifikasi bahwa anak yang diajukan dalam permohonan mengetahui dan menyetujui perkawinan tersebut, hakim juga megidentifikasi tentang kondisi psikologis, kesehatan dan kesiapan anak untuk melangsungkan perkawinan dan membangun rumah tangga dan hakim juga mengindetifikasi bahwa tidak ada paksaan psikis, fisik seksual atau ekonomi terhadap anak dan/atau keluarga untuk kawin atau mengawinkan anak. Maka untuk mendukung tersebut hakim dapat meminta rekomendasi dari Psikolog atau Dokter/Bidan, Pekerja Sosial Profesional, Tenaga Kesejahteraan Sosial, Pusat Pelayanan Terpadu Perlindungan Perempuan dan Anak (P2TP2A), Komisi Perlindungan Anak Indonesia/Daerha (KPAI/KPAD). Di samping itu, hakim dalam menetapkan permohonan dispensasi kawin juga harus mempertimbangkan:

a. Perlindungan dan kepentingan terbaik bagi anak dalam peraturan perundangundangan dan hukum tidak tertulis dalam bentuk nilai-nilai hukum, kearifan lokal dan rasa keadilan yang hidup dalam bermasyarakat; dan

b. Konvensi dan/atau perjanjian internasional terkait perlindungan anak. 
Perubahan norma pada Pasal 7 ayat (1) UU 1/74 tentang batas usia kawin pada UU 16/2019 yang mempersamakan batas minimal usia kawin bagi pria dan wanita pada prinsipnya bertujuan sama sebagaimana pada UU 1/74, yaitu agar calon pasangan matang jiwa raganya untuk dapat melangsungkan perkawinan sehingga dapat mewujudkan tujuan perkawinan secara baik tanpa berakhir pada perceraian dan mendapat keturunan yang sehat dan berkualitas. Diharapkan juga kenaikan batas umur yang lebih tinggi dari 16 (enam belas) tahun bagi wanita untuk kawin akan mengakibatkan laju kelahiran yang lebih rendah dan menurunkan risiko kematian ibu dan anak. Selain itu juga dapat terpenuhinya hak-hak anak sehingga mengoptimalkan tumbuh kembang anak termasuk pendampingan orang tua serta memberikan akses anak terhadap pendidikan setinggi mungkin.

\section{Kesimpulan}

Dengan tidak adanya indikator sama sekali terkait dengan pemberian dispensasi perkawinan, maka dapat dilihat bahwa politik hukum dispensasi perkawinan di dalam UU 1/1974 dan PP 9/1975 memberikan ruang yang besar bagi hakim dalam memberikan dispensasi perkawinan. Dalam perkembangannya, pemberian dispensasi perkawinan yang menitikberatkan pada kewenangan hakim yang ternyata membuat pengajuan dispensasi seolah hanya formalitas belaka yang pasti dikabulkan, maka pembuat Undang-Undang melalui UU 16/2019 memberikan indikator pengajuan dispensasi, yaitu harus dengan alasan mendesak yang wajib disertai dengan bukti-bukti pendukung yang cukup. Hal ini menunjukan, bahwa politik hukum dispensasi perkawinan di dalam UU 16/2019 lebih ketat daripada UU 1/1974 dan memiliki semangat untuk tidak dengan mudah memberikan dispensasi perkawinan.

\section{Daftar Bacaan}

\section{Buku}

Adrian Sutedi, Hukum Perizinan Dalam Sektor Pelayanan Publik (Sinar Grafika 2010).

C.S.T Kansil dan Christine S.T Kansil, Kamus Istilah Aneka Hukum (Surya Multi 
Grafika 2001).

Eddy O.S. Hiariej, Prinsip-prinsip Hukum Pidana Edisi Revisi (Cahaya Atama Pustaka 2015).

I Dewa Gede Atmaja dan I Nyoman Putu Budiarto, Teori- Teori Hukum (Setara Press 2018).

Moh. Idris Ramulyo, Hukum Perkawinan Islam (Sinar Grafindo 1999).

Mahfud MD, Membangun Politik Menegakkan Konstitusi (Rajawali Pers 2010).

Jurnal

Bagya Agung Prabowo, 'Pertimbangan Hakim dalam Penetapan Dispensasi Perkawinan Dini Akibat Hamil di Luar Nikah pada Pengadilan Agama Bantul' (2013) 2 Ius Quiaistum.

Dea Agustina Suardini, Yunanto, dan Mas'ut, 'Pelaksanaan Perkawinan Di Bawah Umur Melalui Dispensasi Pengadilan Agama Kabupaten Indramayu', (2013) 1 Diponegoro Law Review.

Dhorifah Hafidhotul Hikmah, Agung Basuki Prasetyo, dan Triyono, 'Pengaruh Batas Usia Kawin Dalam Undang-Undang Nomor 1 Tahun 1974 Terhadap Jumlah Perkawinan Dibawah Umur Di Kabupaten Rembang Provinsi Jawa Tengah' (2017) 6 Diponegoro Law Journal.

Eddy O.S. Hiariej, 'United Nations Convention Against Corruption Dalam Sistem Hukum Indonesia' (2019) 31 Mimbar Hukum.

Firman Floranta Adonara, 'Prinsip Kebebasan Hakim dalam Memutus Perkara Sebagai Amanat Konstitusi’ (2015) 12 Jurnal Konstitusi.

Khopiatuziadah, 'Evaluasi Dan Analisis Peraturan Perundang-Undangan Dalam Penyusunan Naskah Akademik', (2016) 5 Rechtsvinding

Maisara Sunge, 'Beban Pembuktian Dalam Perkara Perdata' (2012) 9 Jurnal INOVASI.

Maria Rosalina, 'Pengaturan Pemeriksaan Setempat (decentee) Dalam Peraturan PerundangUndangan Di Indonesia' (2018) 18 Jurnal Hukum Kaidah.

Mariyatul Qibtiyah, 'Faktor Yang Mempengaruhi Perkawinan Muda Perempuan' (2014) 3 Jurnal Biometrika dan Kependudukan. 
Moch. Iqbal, 'Aspek Hukum Class Action Dan Citizen Law Suit Serta Perkembangannya Di Indonesia', (2012) 1 Jurnal Hukum dan Peradilan.

Nizar Abdussalam, 'Batas Minimal Usia Kawin Perspektif Hakim Pengadilan Agama dan Dosen Psikologi UIN Malang' (2015) 6 Jurisdictie: Jurnal Hukum dan Syariah.

Nur Aisyah, 'Dispensasi Pernikahan Di Bawah Umur Pada Masyarakat Islam Di Kabupaten Bantaeng' (2017) 4 Jurisprudentie.

Perkawinan Sebagai Bentuk Perlindungan Hukum Terhadap Perempuan (Analisa Putusan MK No. 22/Puu-Xv/2017)' (2019) 2 Lex Scientia.

Nurul Inayah, Penetapan Dispensasi Nilah Akibat Hamil di Luar Nikah di Pengadilan Agama Yogyakarta Tahun 2010-2015 (Analisis Hukum Acara Peradilan Agama) (2017) 10 Al-Ahwal.

Ramadhita,'DiskresiHakim:PolaPenyelesaianKasusDispensasiPerkawinan'(2014) 6 De Jure Jurnal Syariah dan Hukum.

Siti Zya Ama 'Pernikahan Kekerabatan Bani Kamsidin (Studi Kasus Pernikahan Endogami Di Jawa Timur Tahun 1974-2015 M)’ (2017) 1 JUSPI: Jurnal Sejarah Peradaban Islam.

Sri Ahyani,'Pertimbangan Pengadilan Agama Atas Dispensasi Pernikahan Usia Dini Akibat Kehamilan Di Luar Nikah'(2016) 34 Jurnal Wawasan Hukum.

Xavier Nugraha, Krisna Murti, dan Saraswati Putri, 'Third Parties' Legal Protection Over Agreed Authorized Capital Amount By Founders In Limited Liability Companies' (2019) 6 Lentera Hukum.

Xavier Nugraha, Risdiana Izzaty, dan Annida Aqiila Putri, ‘Rekonstruksi Batas Usia Minimal Perkawinan Sebagai Bentuk Perlindungan Hukum Terhadap Perempuan (Analisa Putusan MK No. 22/Puu-XV/2017)' (2019) 2 Lex Scientia

\section{Karya Ilmiah}

Arif Hakiem, 'Pernikahan Dini Karena Paksaan Orang Tua (Studi Kasus di Dusun Menco Kelurahan Berahan Wetan, Kecamatan Wedung, Kabupaten Demak' (Universitas Islam Negeri Sunan Kalijaga Yogyakarta 2009).

M.Muslih, 'Dispensasi Perkawinan di Bawah Umur (Studi Pertimbangan Hakim dalam Memberikan Dispensasi Perkawinan di Peradilan Agama Se-ex Kerasidenan Surakarta)' (Universitas Muhamadiyah Surakarta 2018). 


\section{Perundang-undangan}

Undang-Undang Dasar Negara Republik Indonesia Tahun 1945.

Undang-Undang Nomor 1 Tahun 1974 Tentang Perkawinan.

Undang - Undang Nomor 48 Tahun 2009 Tentang Kekuasaan Kehakiman.

Undang Nomor 11 Tahun 2012 Tentang Sistem Peradilan Anak.

Undang-Undang Nomor 16 Tahun 2019 Tentang Perubahan Atas Undang-Undang Nomor 1 Tahun 1974 Tentang Perkawinan.

Peraturan Pemerintah Nomor 9 Tahun 1975 Tentang Peraturan Pelaksana UndangUndang Nomor 1 Tahun 1974 Tentang Perkawinan.

Peraturan Mahkamah Agung Republik Indonesia Nomor 5 Tahun 2019 tentang Pedoman Mengadili Permohonan Dispensasi Kawin

\section{Putusan}

Putusan Mahkamah Konstitusi Nomor 22/PUUXV/2017.

Penetapan Nomor 0978/Pdt.P/2017/PA.Kab.Mlg.

How to cite: Trisadini Prasastinah Usanti, Xavier Nugraha dan Dita Elvia Kusuma Putri, 'Analisis Perubahan Politik Hukum Dispensasi Perkawinan Pasca Undang-Undang Nomor 16 Tahun 2019’ (2021) Vol. 4 No. 3 Notaire. 